\title{
Assessment of the Possibility of Hydrometallurgical Processing of Low-Grade Ores in the Oxidation Zone of the Malmyzh Cu-Au Porphyry Deposit
}

\author{
Arthur Sekisov (D) and Anna Rasskazova *(D) \\ Mining Institute of the FEB RAS, 680000 Khabarovsk, Russia; sekisovag@mail.ru \\ * Correspondence: annbot87@mail.ru; Tel.: +79-141-871-569
}

Citation: Sekisov, A.; Rasskazova, A Assessment of the Possibility of Hydrometallurgical Processing of Low-Grade Ores in the Oxidation Zone of the Malmyzh Cu-Au Porphyry Deposit. Minerals 2021, 11, 69. https://doi.org/10.3390/ $\min 11010069$

Received: 17 November 2020 Accepted: 8 January 2021 Published: 12 January 2021

Publisher's Note: MDPI stays neutral with regard to jurisdictional clai$\mathrm{ms}$ in published maps and institutional affiliations.

Copyright: (C) 2021 by the authors. Licensee MDPI, Basel, Switzerland. This article is an open access article distributed under the terms and conditions of the Creative Commons Attribution (CC BY) license (https:// creativecommons.org/licenses/by/ $4.0 /)$.

\begin{abstract}
The geochemical features of the ores present in the oxidation zone of the gold-copper Malmyzh mineral deposit are characterized. This deposit is located in the the Nanaian region of the Khabarovsk Territory in the Russian Federation, and a technological assessment of ores present was carried out. The initial gold content in the oxidized ore is 0.1-1.2 ppm, and the leachability of gold from different size fractions by hot cyanide revealed the fact that the ore is not refractory and characterized by increased cyanide consumption. The results demonstrated a high gold content in fine size fractions. Different leaching reagents were applied for oxidized ore testing. These reagents were used both for oxidative pretreatment and leaching process. Activation of solutions was carried out by electrolysis and UV radiation. Different reagent combinations were tested in laboratory with the highest gold recovery ( $94 \%$ ) provided by the chloride system with peroxide-sulfuric pretreatment of the oxidized ore. The same reagent combination resulted in $91-94 \%$ gold recovery during the column leaching of crushed $(-10 \mathrm{~mm})$ ore.
\end{abstract}

Keywords: copper-gold mineral deposit; oxidized ore; carbonaceous solution; ammonium cyanide solution; peroxide-sulfuric solution; chloride reagent complex; pretreatment; electrolysis

\section{Introduction}

The Malmyzh deposit is a promising world-class copper deposit located in the Nanaian region of the Khabarovsk Territory. The deposit was discovered in 2006, and the reserves are 1.3 billion tons of ore. The balance of reserves present in the deposit are estimated at 5.156 million tons of copper and 278 tons of gold. There are plans to build a modern mining and processing plant with a 56-million-tons-of-ore-per-year capacity by 2023. The main technology planned for processing copper ores is flotation, suitable for primary copper sulfide ores. Large volumes of oxidized ore are planned to be stored in dumps, and this study investigates the possibility of hydrometallurgical processing of oxidized ores by heap leaching.

Hydrometallurgical processing of complex ores and concentrates is becoming increasingly important because the mining and metallurgical industry seeks to exploit mineral deposits that are difficult to treat using conventional mineral processing and pyrometallurgical technologies. Mineral processing is often challenged by the difficulty or inability to separate valuable minerals into marketable concentrates. Using hydrometallurgical processing and selective leaching technology can often chemically beneficiate such difficult deposits and is generally lower in capital cost for an equivalent metal production rate while avoiding the gas and dust issues associated with pyrometallurgical processing [1]. While pyrometallurgical processing is an established technology and the dominant and logical route used to treat sulfide concentrates, there are alternative hydrometallurgical processes [2]. 


\subsection{Malmyzh Deposit, General Information}

The copper-gold porphyry Malmyzh deposit is located in the Nanaian region of the Khabarovsk Territory. The geology, reserve and resource base map (Figure 1) is available at the IG copper web site [3].

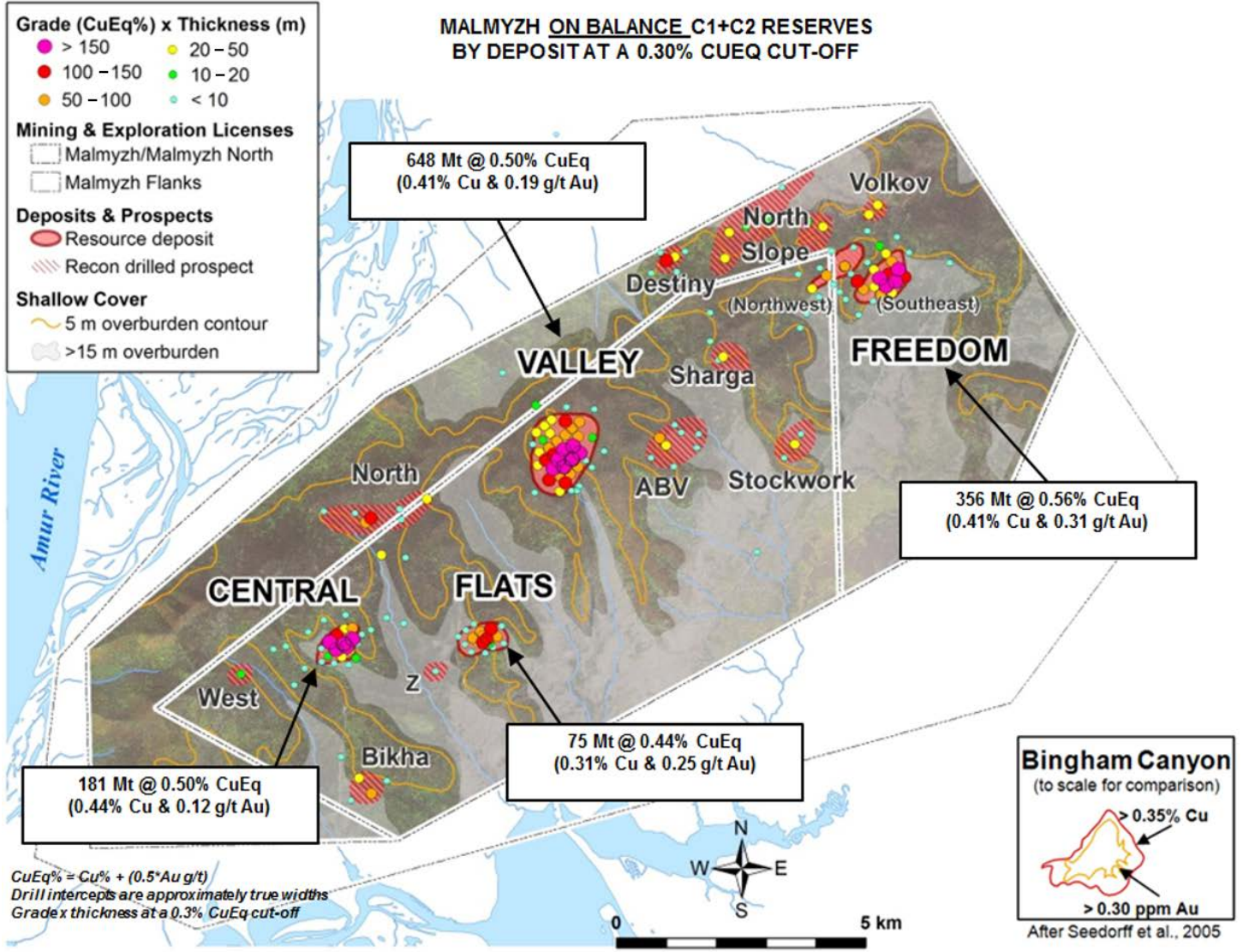

Figure 1. Geology, Reserve and Resource Base.

As gold is less reactive than copper, the $\mathrm{Au} / \mathrm{Cu}$ ratio increases in oxidized ores in comparison with primary sulfides. As a result, the copper content is under the flotation economic cutoff grade $(0.55 \%)$ while gold content is low grade. Low-grade ores are economically viable only in the presence of a feasible application of physical and chemical geotechnologies, such as heap leaching.

Ores of the oxidation zone of the Malmyzh deposit typically have a copper content less than $0.3 \%$ and a $0.1-1.2 \mathrm{ppm}$ gold content. Subeconomic copper content is $<0.55 \mathrm{wt} \%$ and subeconomic gold content is less than $0.3 \mathrm{ppm}$. If this ore is categorized as low grade (not overburden), it is possible to lower the current overburden coefficient and cost of extraction from the ore. Assessment of the gold content of exploration drill samples demonstrates the possibility of a delineation of sites with the standard gold content within the oxidation zone of this mineral deposit. Selective mining of the ore makes the heap leaching method economically viable. Beneficiation using gravity concentration techniques is not appropriate for finely disseminated ore minerals and minerals of similar density as the gangue. Also, the flotation processing of oxidized Malmyzh ores is not viable for two reasons. Firstly, flotation requires a high level of expenditure for crushing/milling which can result in considerable gold losses because of fine size fractions caused by over-milling. Secondly, friable iron oxide and the hydroxide minerals and copper oxide minerals contain encapsulated and dispersed gold. The presence of pyrite makes a significant improvement in gold leaching because of the positive galvanic interactions [4]. 
Hydrometallurgical methods of processing oxidized copper ores are widely used [5], and heap leaching is also a feasible method.

The Malmyzh oxidized ore is not refractory for leaching process. There are no major complicating factors such as the presence of residual sulfide minerals and sorption-active carbonaceous substances. Gold is mainly occurring as dispersed and encapsulated in the oxidized ores. It is concentrated in minerals that are permeable for the leaching reagents, and the oxidized ores have acceptable porosity. Particular problems with this methodology include high output of fine size fractions and the necessity for ore agglomeration before heap leaching.

Significant amounts of chemical elements that are consumers of cyanide are presented in oxidized ores of the Malmyzh deposit. These include iron, copper and manganese. The manganese admixture in the ore (up to $90 \mathrm{ppm}$ ) oxidizes the cyanides and transforms them to cyanates. Therefore, novel reagents are investigated for processing Malmyzh oxidized ores.

\subsection{Review of Methods of Gold Leaching from Copper-Bearing Ores}

Ammoniacal-cyanide or thiosulfate leaching is applicable for gold extraction from copper-bearing ores. It is well known that copper reacts with cyanide solutions with the formation of toxic copper and cyanic complexes of the following compositions: $\mathrm{Cu}(\mathrm{CN})^{2-}$, $\mathrm{Cu}(\mathrm{CN})_{3}{ }^{2-}, \mathrm{Cu}(\mathrm{CN})_{4}{ }^{3-}$. Thus, the majority of cyanide is consumed by copper, which interferes with gold extraction [6]. Recent directions of research concerning the processing of gold-copper ores are mainly devoted to the addition of ammonium to the standard process of cyanidation and reduction of cyanide for leaching [7-10]. Sea water is also used for the activation of chlorides and strengthening of leaching solutions at a number of operations in Chile and the USA [11].

The ability of some typical gangue minerals and activated carbon to adsorb gold (I) (preg-robbing) in nonammoniacal thiosulfate solutions is well-known. In the absence of calcium thiosulfate, sulfide minerals such as pyrite and chalcopyrite as well as carbon were highly preg-robbing with $100 \%$ gold adsorbed within half an hour. The oxide minerals examined including kaolinite, goethite and hematite were significantly less preg-robbing under the same conditions. The presence of free thiosulfate can significantly reduce or eliminate preg-robbing of gold on mineral surfaces. Copper (I) was found to enhance the preg-robbing of gold by oxide minerals but reduced the preg-robbing of gold caused by sulfide minerals and carbon [12]. The process of bioleaching has also been applied for low-grade metal sulfide ores [13]. At the same time, low sulfide flotation tailings can be processed by bioleaching with mixed acidophilic cultures, which is applied as a pretreatment process for the recovery of nickel, cobalt and zinc as well as for iron removal. Dissolution of gold and copper was not observed in this process. The residues from the bioleaching pretreatment were then applied to chemical chloride leaching to extract gold and copper into the solution. In chloride leaching, the highest extractions of copper and gold were $98 \%$ and $63 \%$, respectively, and the highest extractions of iron, copper, gold, nickel, cobalt and zinc were observed with biologically pretreated feed [14].

Research into direct cyanide leaching of copper-sulfide gold-bearing ores has included ammonium pre-leaching and ammonium-cyanide leaching, with a strong influence of copper sulfides on cyanide solutions shown. It was established that the concentration of $\mathrm{NaCN}$ should not be lower than $5 \mathrm{~g} / \mathrm{L}$. Ammonium processing of ores before leaching reduces the influence of copper, providing almost complete extraction of gold with accompanying low consumption of reagent during subsequent cyanide leaching $[15,16]$. Ammonium pretreatment and ammonium cyanide leaching is a prospective method for processing of gold-bearing ores with the high content of copper sulfide [17-19]. The effects of adding ammonia during the cyanidation of copper-gold ores are complex, but under the right conditions, the consumption of cyanide can be substantially reduced. This is generally ascribed to the oxidation of $\mathrm{Cu}(\mathrm{I})$ in the cuprous cyanide complexes and the stabilization of $\mathrm{Cu}$ (II) in solution, due to the formation of the tetra-ammino-cupric complex 
ion, $\mathrm{Cu}\left(\mathrm{NH}_{3}\right)_{4}{ }^{2+}$, thus releasing all the cyanide that would otherwise be bound into the cuprous cyanide complex ions [20].

Research of noncyanide (thiosulfate) leaching of pure gold and concentrate of refractory gold-bearing oxidized ore in the autoclave was executed with the application of thiosulfate-copper and ammonium solutions. The reagent composition of the applied solution was as follows: $0.2 \mathrm{M} \mathrm{Na}_{2} \mathrm{~S}_{2} \mathrm{O}_{3}, 0.6 \mathrm{M} \mathrm{NH}_{3}, 0.01 \mathrm{M} \mathrm{CuSO}_{4}, 0.4 \mathrm{M} \mathrm{Na}_{2} \mathrm{SO}_{4}$. The total recovery of gold based on the analysis of the leaching residue varies within the range $81-89 \%$. More diluted pulp provided higher rates of extraction of the target component [21].

Gold leaching of oxidized copper refractory ore (Tarror mineral deposit) demonstrated low gold recovery by direct cyanidation. The reason was the high copper content present because it forms stable copper-cyanic complexes. Application of ammonium compounds to oxidized ores provides high rates of gold recovery and prevents the formation of copper complexes in pregnant solution. An expected decrease in the consumption of cyanide was also observed [22]. Thus, analysis of literary data showed that ammonium leaching can be a viable processing option for Malmyzh gold-copper ores.

\section{Materials and Methods}

\subsection{Characteristics of Malmyzh Oxidized Ore}

Sampling via exploratory drilling on the site "Freedom" was carried out for the preliminary laboratory analytical and technological testing.

The mineralogical analysis of ores of the oxidation zone of site Freedom of the Malmyzh deposit showed that the main constituents of the oxidized ore are limonite, goethite, magnetite, pyrite, azurite and malachite [23]. Minerals chemically inert with respect to cyanide solutions comprised quartz, plagioclase, micas, clay minerals and amphibole. Free gold was not found in the studied samples despite their elevated gold content (0.3-1 ppm). This suggested the presence of encapsulated and dispersed modes of occurrence. Metal content of the representative sample (TP-6S-O) is $0.8-1 \mathrm{ppm} \mathrm{Au}, 12.2 \% \mathrm{Fe}$, $0.09 \% \mathrm{Cu}$ and $90 \mathrm{ppm} \mathrm{Mn}$.

\subsection{Methods of Leaching Solution Preparation}

Laboratory vat leaching was carried out before percolation experiments with various reagent compositions tested. The following compositions of leaching solutions were used.

2.2.1. Ore Preparation by Activation in Electrochemical and Photochemical Reactors Containing Peroxide-Carbonaceous Solutions (Peroxide Complexes Are Formed in an Aqueous Medium during Electrochemical and Photochemical Processing). Gold Leaching by Ammonium Cyanide Solution

Use of this scheme resulted in a decrease in solubility of copper by formation of its carbonaceous compounds and binding of $\mathrm{Cu}$ ions leached to pregnant solution by ammonium complexes. In general, it reduces cyanide consumption due to reactions with copper.

Carbonate solution $\left(10 \mathrm{~g} / \mathrm{L} \mathrm{NaHCO}_{3}\right)$ was activated by electrolysis and UV radiation with hydrogen peroxide added to the carbonate solution before the UV radiation. The oxidation-reduction potential was increased as a result of the activation process. The reagent composition of the applied solution at the second stage was $\mathrm{NaCN}+\mathrm{NH}_{4} \mathrm{OH}$.

2.2.2. Ore Preparation for Leaching by the Active Peroxide-Sulfuric Solutions (Activation in Electrochemical and Photochemical Reactors). Subsequent Gold Leaching by Solutions with Cyanide and Chloride Reagent Basis

Sulfate leaching $\left(\mathrm{H}_{2} \mathrm{SO}_{4}, \mathrm{pH}=3\right)+\mathrm{H}_{2} \mathrm{O}_{2}$; sulfuric acid and peroxide react to form Caro's acid $\left(\mathrm{H}_{2} \mathrm{SO}_{5}\right)$ [24]:

$$
\mathrm{H}_{2} \mathrm{SO}_{4}+\mathrm{H}_{2} \mathrm{O}_{2}=\mathrm{H}_{2} \mathrm{SO}_{5}+\mathrm{H}_{2} \mathrm{O}
$$


Instead of peroxide in Caro's acid, in the process of electrolysis peroxydisulfate ions take part in the oxidation reaction (2):

$$
\begin{gathered}
\text { Anode: } 2 \mathrm{HSO}_{4}{ }^{-}=\mathrm{S}_{2} \mathrm{O}_{8}{ }^{2-}+2 \mathrm{H}^{+}+2 \mathrm{e}^{-} \\
2 \mathrm{SO}_{4}{ }^{2-}=\mathrm{S}_{2} \mathrm{O}_{8}{ }^{2-}+2 \mathrm{e}^{-} \\
\text {Cathode: } 2 \mathrm{H}^{+}+2 \mathrm{e}^{-}=\mathrm{H}_{2}
\end{gathered}
$$

Copper leaching using sulphuric acid and hydrogen peroxide mixtures is more effective than sulfuric leaching without hydrogen peroxide [25].

The sodium cyanide concentration was $0.05 \%$. Active chloride-based leaching solution was prepared by electrolysis of $\mathrm{NaCl}$ solution $\left(\mathrm{C}_{0}(\mathrm{NaCl})=20 \mathrm{~g} / \mathrm{L}\right)$. Hydrochloric acid $(\mathrm{HCl})$ was added to the solution during the final stage of electrolysis until neutral $\mathrm{pH}$ was achieved. The obtained solution was then UV-radiated.

Ore preparation by activated peroxide-sulfuric solutions was used for the passivation of iron. Iron was fixed on the contact surface of the iron-bearing oxide- and oxide-hydroxide minerals by generating sulfate-oxide:

$$
\begin{aligned}
& \mathrm{Fe}_{2} \mathrm{O}_{3}+2 \mathrm{H}_{2} \mathrm{SO}_{4} \times \mathrm{nH}_{2} \mathrm{O} \times \mathrm{H}_{2} \mathrm{O}_{2}=2\left[\mathrm{Fe}(\mathrm{OH})\left(\mathrm{SO}_{4}\right)\right] \mathrm{O} \times(\mathrm{n}+2) \mathrm{H}_{2} \mathrm{O} \\
& 2\left[\mathrm{Fe}(\mathrm{OH})\left(\mathrm{SO}_{4}\right)\right] \mathrm{O} \times(\mathrm{n}+2) \mathrm{H}_{2} \mathrm{O}+2 \mathrm{H}_{2} \mathrm{SO}_{4}=\mathrm{Fe}_{2}\left(\mathrm{SO}_{4}\right)_{3}+(\mathrm{n}+5) \mathrm{H}_{2} \mathrm{O}
\end{aligned}
$$

Iron sulfate-oxide (distinct from $\mathrm{FeSO}_{4}$ ) does not reduce gold cation (as a part of a complex anion) and, therefore, does not precipitate it from solution to a mineral phase. Besides, iron oxide inside sulfate-oxide composition (sulfate complex), does not interact with cyanide or with active chlorine. It prevents leaching reagent consumption for undesirable interactions and catalyzes the process of complexing of disperse gold due to availability of the clustered oxygen in structure of "free" (not bound with iron atoms) parts of $\mathrm{Fe}_{2}\left(\mathrm{SO}_{4}\right)_{3}$ molecule. It was proved that the sulfation process applied to produce a pregnant solution contained higher amounts of $\mathrm{Cu}$ metal by reducing the iron concentration in leaching process [26]. The clustered oxygen unites hydroxonium ions in the complex, and $\mathrm{CN}^{-}$or $\mathrm{Cl}^{-}$anions via them. Thus, the probability of a cluster reaction between untied complexing agents and gold significantly increases.

\subsubsection{Direct Gold Leaching by Active Chloride-Based Reagent (without Pre-Treatment)}

Active chloride-based leaching solution was prepared by electrolysis of $\mathrm{NaCl}$ solution (initial concentration of $\mathrm{NaCl}$ is $20 \mathrm{~g} / \mathrm{L}$ ). Hydrochloric acid $(\mathrm{HCl})$ was added to the solution in the final stage of electrolysis until neutral $\mathrm{pH}$ is achieved. The obtained solution was UV-radiated. Sodium hypochlorite $(\mathrm{NaClO})$ is formed in the inter-electrode space [27]. The main reaction at the cathode is:

$$
2 \mathrm{H}_{2} \mathrm{O}+2 \mathrm{Na}^{+} \rightarrow 2 \mathrm{NaOH}+\mathrm{H}_{2}
$$

While the reaction at the anode is:

$$
\begin{gathered}
2 \mathrm{Cl}^{-}-2 \mathrm{e} \rightarrow \mathrm{Cl}_{2} \\
2 \mathrm{H}_{2} \mathrm{O}+\mathrm{Cl}_{2} \leftrightarrow \mathrm{HClO}+\mathrm{H}^{+}+\mathrm{Cl}^{-}
\end{gathered}
$$

General reaction of formation of sodium hypochlorite is:

$$
\mathrm{HClO}+\mathrm{NaOH} \rightarrow \mathrm{NaOCl}+\mathrm{H}_{2} \mathrm{O}
$$

Extremely active oxidizers are produced in the process of UV-radiation of the watergas emulsion formed during electrolysis. These oxidizers are atomic oxygen, atomic chloride, superoxide radical ion $\left(\mathrm{O}^{*-}\right)$, ozone $\left(\mathrm{O}_{3}\right)$, hydroxyl radical $\left(\mathrm{OH}^{*}\right)$, and hypochlorite radical $\left(\mathrm{ClO}^{*}\right)$. Clustered hydrated complexes are produced at electro-photochemical 
processing of aqueous solutions of lixiviant. These complexes are highly active in relation to a coated part of a gold cluster [28,29].

Bivalent copper and trivalent iron in chloride solutions can play a catalytic role, clustering hydrated chlorine ions. It increases the probability of chemical interactions between clustered chloride and gold. Therefore, chloride consumption can be low during the gold leaching of oxidized copper ore. Copper can play a catalytic role in the transformation of copper-ammonium complexes to copper-cyanide in cyanide solutions. In common alkalinecyanide solutions, copper, as well as iron, forms strong cyanide complexes, competing with gold complexing agents. Therefore, sodium cyanide consumption is elevated during leaching of oxidized copper-porphyritic ore.

Cyanide leaching with high sodium cyanide $(0.7 \%)$ concentration was the reference leaching scheme. It provides almost complete, but not selective gold leaching. This gold recovery system makes possible the establishment of a leachability proxy for comparing the degree of gold in dispersed and encapsulated forms by a given complexing agent. A common cyanide concentration $(0.05 \%)$ was applied for the assessment of a portion of cyanide consumption by manganese oxides. Cyanide solutions had $\mathrm{pH}=10.5$ in all experiments.

\section{Results and Discussion}

\subsection{Results of Hot Cyanide Solution Leaching}

The results of hot cyanide leaching from different size fractions of the Malmyzh oxidized ore are presented in Table 1. The gold content of grain-size fractions of crushed ore (Table 1), leached by hot cyanide solution, showed that gold is mainly bounded to the fine size fractions $(-0.2+0.1 \mathrm{~mm}$ and $-0.1+0 \mathrm{~mm})$.

Table 1. Recovery of $\mathrm{Au}, \mathrm{Ag}, \mathrm{Cu}$ and $\mathrm{Fe}$ ) from various size fractions of oxidized sample of Malmyzh deposit by hot cyanide.

\begin{tabular}{cccccccc}
\hline \multirow{2}{*}{ Size Fraction, $\mathbf{m m}$} & Portion, & \multicolumn{3}{c}{ Element Recovery, mg/L } & \multicolumn{2}{c}{ Ratio } \\
& $\mathbf{w t} \%$ & $\mathbf{A u}$ & $\mathbf{A g}$ & $\mathbf{C u}$ & $\mathbf{F e}$ & $\mathrm{Au} / \mathbf{F e}$ & $\mathbf{A u} / \mathbf{C u}$ \\
\hline$-5+2$ & 39.61 & 0.66 & 0.19 & 34.58 & 83.73 & 0.0078 & 0.019 \\
$-2+1$ & 13.94 & 0.48 & 0.25 & 38.76 & 78.54 & 0.0061 & 0.012 \\
$-1+0.5$ & 16.26 & 0.45 & 0.33 & 36.98 & 92.78 & 0.0048 & 0.012 \\
$-0.5+0.2$ & 13.49 & 0.58 & 0.40 & 38.88 & 106.50 & 0.0054 & 0.015 \\
$-0.2+0.1$ & 5.23 & 0.92 & 0.57 & 49.67 & 145.01 & 0.0063 & 0.0185 \\
$-0.1+0$ & 11.47 & 1.16 & 0.64 & 59.39 & 150.53 & 0.0077 & 0.0195 \\
$\mathrm{C}_{\max } / \mathrm{C}_{\min }$ & & 2.57 & 3.37 & 1.71 & 1.79 & & \\
\hline
\end{tabular}

The ratio of maximum and minimum element recovery to pregnant solution demonstrates the nonuniformity of its distribution through size fractions. This indicator is high for gold (2.57) and silver (3.37) and low for copper and iron. Ratio of $\mathrm{Au} / \mathrm{Fe}$ and $\mathrm{Au} / \mathrm{Cu}$ in pregnant solution denotes the content of cyanide consuming constituents.

\subsection{Electrochemical and Photochemical Activation of Leaching Solutions}

During the first stage of laboratory research, technological testing of samples (TP-6S-O) was carried out for the assessment of gold leachability by solutions with various composition of complexing agent and their concentration. Laboratory testing experiments included stirred vat leaching of ore crushed to $60 \%$ passing $0.071 \mathrm{~mm}$ for all reagent schemes.

Additional output parameters measured included the content of cyanide consuming elements in the pregnant solution (iron and copper). In this regard, pre-treatment was used before ore leaching to alleviate any surface passivation of iron and cupriferous minerals. This pre-treatment leads to the development of additional microdefects in the crystal lattice providing enhancement of permeability of the heap for leaching solutions.

Application of ammonium complex and chloride complexing agent for gold extraction is reasonable because of the high concentration of cyanide consumers in the oxidized 
Malmyzh ore. Variations in lixiviant concentrations were assessed in the gold leaching process.

Taking into account the necessity of ore pre-treatment and real industrial economic viability, gold leaching was conducted with the use of sulfuric acid and carbonaceous $\left(\mathrm{NaHCO}_{3}\right)$. The method of gold leaching from refractory ore was developed in Khabarovsk Federal Research Center. The first stage is processing the ore by a sulfuric-peroxide solution with the complex of highly-active hydrated oxidizers and subsequent chloride leaching. Activation included electrochemical and photochemical processing (Figure 2) [30].

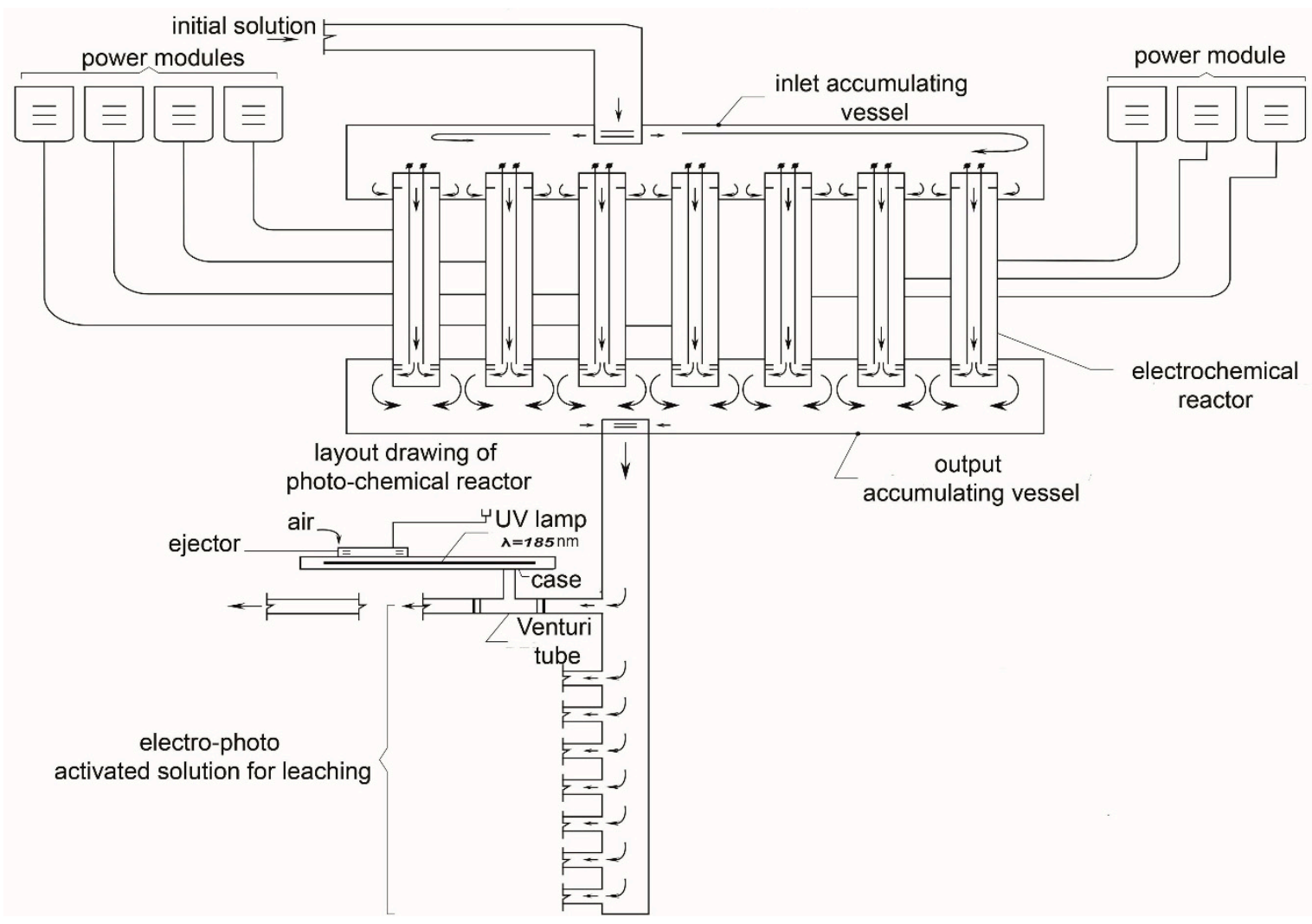

Figure 2. Layout drawing of photo-elecro-chemical reactors.

Crushed ore $(-10 \mathrm{~mm})$ is mixed with cement $(0.3-0.5 \%)$ and activated solution is added to the mixture for agglomeration. Ore agglomerates were loaded into percolation columns (Figure 2). Agglomerate curing lasted three days allowing oxidative process in ore to take place via flow diffusion, following which agglomerates are irrigated with chloride solution.

\subsection{Results of Leaching Experiments}

Gold content in oxidized ore samples for vat leaching experiments was $1 \mathrm{ppm}$ with a liquid-to-solid ratio of $1 / 1$. The results of vat leaching are summarized in Table 2 . The highest gold recovery was provided by the system with chloride leaching in conjunction with peroxide-sulfuric ore pretreatment. 
Table 2. Results of the laboratory experiments of gold leaching.

\begin{tabular}{|c|c|c|c|c|c|c|}
\hline \multirow{2}{*}{ Leaching Reagents } & \multirow{2}{*}{ Gold Recovery, \% } & \multirow{2}{*}{ SD } & \multicolumn{4}{|c|}{ Recovery to Pregnant Solution, mg/L } \\
\hline & & & $\mathrm{Au}$ & $\mathrm{Ag}$ & $\mathrm{Cu}$ & $\mathrm{Fe}$ \\
\hline Cyanide $\left(\mathrm{C}_{\mathrm{NaCN}}=0.7 \%\right)$ & 93 & 0.01 & 0.93 & 0.42 & 32.3 & 390.7 \\
\hline Cyanide $\left(\mathrm{C}_{\mathrm{NaCN}}=0.05 \%\right)$ & 65 & 0.08 & 0.65 & 0.30 & 29.8 & 32.9 \\
\hline $\begin{array}{l}\text { Peroxide-sulfuric preparation and } \\
\text { cyanide leaching }\left(\mathrm{C}_{\mathrm{NaCN}}=0.05 \%\right)\end{array}$ & 80 & 0.04 & 0.80 & & 21.5 & 7.1 \\
\hline $\begin{array}{l}\text { Peroxide-sulfuric preparation and } \\
\text { chloride leaching }\end{array}$ & 94 & 0.03 & 0.94 & & 7.7 & 8.9 \\
\hline $\begin{array}{c}\text { Carbonaceous preparation and } \\
\text { cyanide-ammonia leaching }\end{array}$ & 81 & 0.05 & 0.81 & & 13.5 & 34 \\
\hline Chloride leaching & 64 & 0.13 & 0.64 & 0.33 & 0.45 & 0 \\
\hline
\end{tabular}

SD—standard deviation of gold recovery in parallel experiments.

Direct chloride leaching (without preliminary peroxide-sulfuric preparation) demonstrates a recovery of $0.64 \mathrm{mg} / \mathrm{L}$ gold. Chloride leaching with peroxide-sulfuric pretreatment gave $0.94 \mathrm{mg} / \mathrm{L}$ gold recovery. We conclude that preparation by peroxide-sulfuric solutions passivates the surface of the ore minerals.

The same conclusion can be drawn when comparing gold recovery by cyanidation $\left(\mathrm{C}_{\mathrm{NaCN}}=0.05 \%\right)$ and cyanide leaching $\left(\mathrm{C}_{\mathrm{NaCN}}=0.05 \%\right)$ with preliminary peroxide-sulfuric ore preparation. Gold recovery by cyanidation is $0.65 \mathrm{mg} / \mathrm{L}$. Peroxide-sulfuric ore preparation followed by cyanide leaching increases gold recovery up to $0.80 \mathrm{mg} / \mathrm{L}$. The lowest copper recovery is provided by peroxide-sulfuric ore preparation and chloride leaching (7.7 mg/L). In comparison $29.8 \mathrm{mg} / \mathrm{L}$ was obtained by cyanidation $\left(\mathrm{C}_{\mathrm{NaCN}}=0.05 \%\right)$ and $13.5 \mathrm{mg} / \mathrm{L}$ by cyanide-ammoniac leaching with peroxide-carbonaceous preparation.

Iron and copper are not extracted in significant quantities to the pregnant solution as a result of chloride leaching. Gold recovery is characterized by fast kinetics $(0.64 \mathrm{mg} / \mathrm{L}$ in $2 \mathrm{~h}$ vat leaching and less than $0.1 \mathrm{mg} / \mathrm{L}$ in $4 \mathrm{~h}$ ). Possibly, it relates to the formation of chloride-hypochlorite iron (oxidation level $\mathrm{Fe}^{+3}$ ) and copper complexes. These complexes are transformed to hydroxide complexes as a result of disproportionation and growth $\mathrm{pH}$ in film water. Freshly synthesized iron hydroxides have sorption properties, and this may relate to a decrease in gold concentration in pregnant solution during aging.

A laboratory column leaching experiment to investigate the recovery of gold and copper from oxidized ores of Malmyzh deposit was carried out on $250 \mathrm{~g}$ samples. Ore was crushed to a particle size of $-10 \mathrm{~mm}$ before column loading. During the first stage, the oxidized ore was pre-treated with a sulfuric acid-peroxide solution $(\mathrm{S} / \mathrm{L}=3.5)$. After this, oxidation ore samples were irrigated with photo-electro activated chloride-hypochlorite solution for 25 days. Reagent consumption over this period was $100 \mathrm{~mL} / \mathrm{kg} \times$ day. Sulfuricperoxide leach solution was applied at the final stage of experiment (25-35 days). Parallel experiments gave a gold recovery of $91-94 \%$, with the gold, silver and copper recovery demonstrated in Figure 3. 


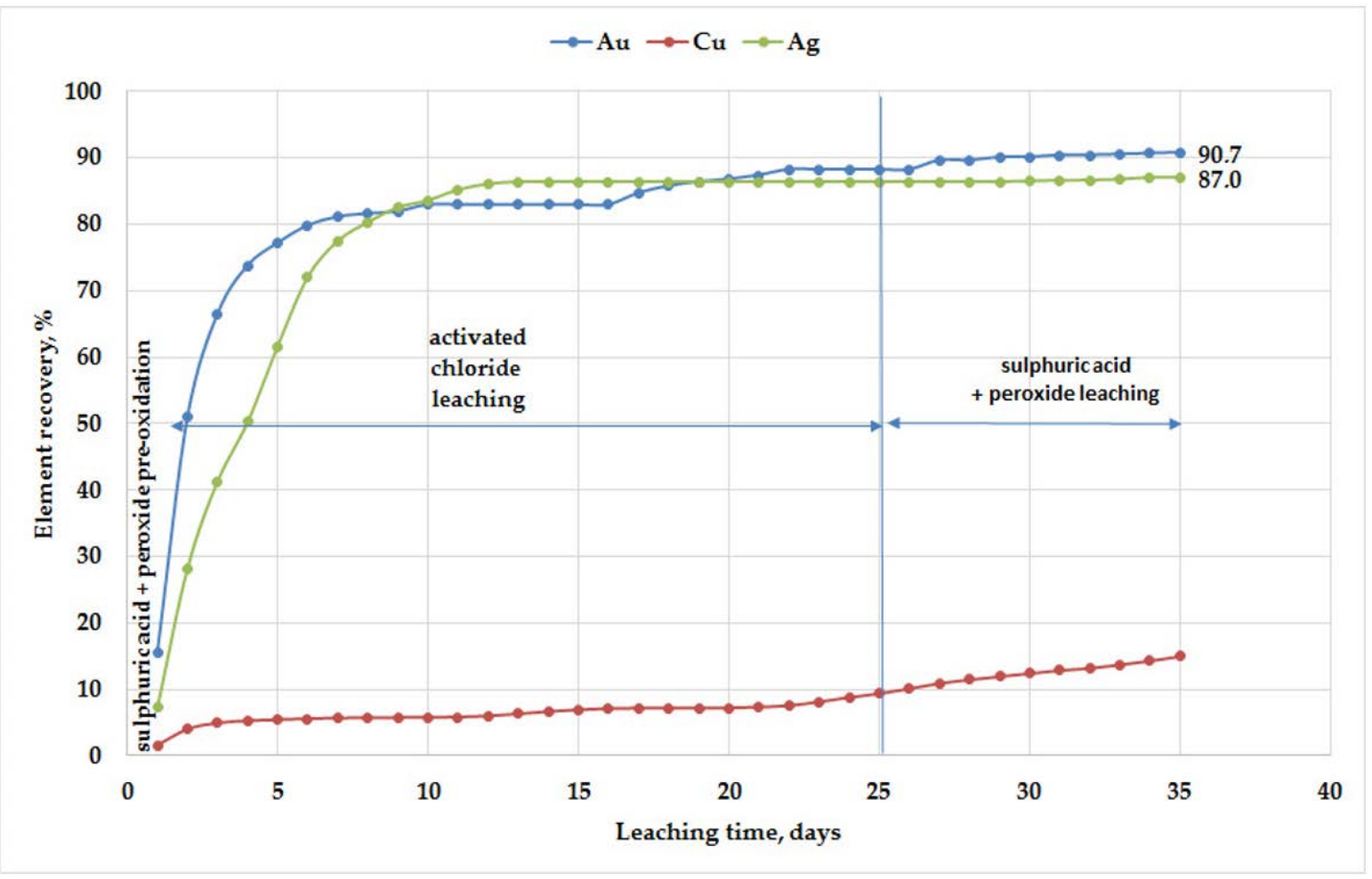

Figure 3. Gold, copper and silver extractions of oxidized ore during column leaching.

\section{Conclusions}

Ores located in the oxidation zone of the Malmyzh deposit are characterized by low copper and gold contents $(<0.3 \% \mathrm{Cu}$ and $0.1-1.2 \mathrm{ppm} \mathrm{Au})$. The possibility of their hydrometallurgical processing was studied by vat leaching tests with different lixiviants in the first stage. Column leaching tests were used to simulate heap leaching carried out with lixiviants that previously demonstrated good results for vat leaching.

1. Vat leaching tests included different leaching solution compositions: cyanide ( 0.7 and $0.05 \%$ ); cyanidation after sulfuric-peroxide preparation and cyanide-ammoniac leaching after ore carbonaceous preparation. Leaching by electro-photo activated chloride solution after sulfuric-peroxide preparation was tested along with direct chloride leaching.

Direct cyanide leaching by highly concentrated solutions $\left(\mathrm{C}_{\mathrm{NaCN}}=0.7 \%\right)$ provided $94 \%$ gold recovery. Cyanide consumption at this concentration is too high for this process to be economical. Peroxide-sulfuric preparation by electro-activated solution and chloride leaching results in $94 \%$ of gold recovery.

2. Laboratory-scale column gold leaching from crushed $(-10 \mathrm{~mm})$ oxidized ore simulated the physical, chemical, hydrodynamic and geochemical processes of heap leaching. Peroxide-sulfuric preparation and the chloride column leaching resulted in $91-94 \%$ gold recovery to pregnant solution.

Gold recovery rates during vat and column leaching demonstrate the effectiveness of preliminary passivation of surface of ore minerals by peroxide-sulfuric solutions. The oxidation-reduction potential of these leaching solutions, their chemical composition and oxidative ability increased as a result of electro-photo activation. Cyanide-free combination of peroxide-sulfuric preparation and activated chloride leaching provides high gold recovery from oxidized ore of Malmyzh deposit.

Author Contributions: Conceptualization, A.S.; investigation, A.R.; methodology, A.S.; writingoriginal draft, A.R. All authors have read and agreed to the published version of the manuscript.

Funding: Research funded by Russian Academy of Sciences (AAAA-A18-118020690004-1). 
Institutional Review Board Statement: Not applicable.

Informed Consent Statement: Not applicable.

Data Availability Statement: The experimental data presented in this study are available on request from the corresponding author. The geology, reserve and resource base data presented in this study are openly available [3].

Acknowledgments: Authors would like to express gratitude to O'Connor, Director of the Centre for Minerals Research at the University of Cape Town and the President of International Mineral Processing Council, for giving helpful comments to this paper that helped to improve it. Authors express thanks to N.M. Litvinova, T.G. Konareva, K.V. Prokhorov and M.S. Kirilchuk for the assistance in the laboratory research. Assays and mineral composition research were performed on the basis of the Center for shared use of scientific equipment "Mineral Research Center" of the Khabarovsk Federal Research Center of the Far Eastern Branch of the Russian Academy of Sciences.

Conflicts of Interest: The authors declare no conflict of interest.

\section{References}

1. Dreisinger, D. Keynote address: Hydrometallurgical process development for complex ores and concentrates. J. S. Afr. Instit. Min. Metall. 2009, 109, 253-271.

2. Habashi, F. Recent trends in extractive metallurgy. J. Min. Met. Sect. B Met. 2009, 45, 1-13. [CrossRef]

3. IG Copper LLC, Malmyzh Mineral Deposit. Geology, Reserve \& Resource Base. Available online: http://igcopper.net/malmyzh/ (accessed on 28 January 2020).

4. Larachi, F.; Larachi, F. The effect of flotation collectors on the electrochemical dissolution of gold during cyanidation. Miner. Eng. 2019, 130, 48-56. [CrossRef]

5. Bobadilla-Fazzini, R.A.; Pérez, A.; Gautier, V.; Jordan, H.; Parada, P. Primary copper sulfides bioleaching vs. chloride leaching: Advantages and drawbacks. Hydrometallurgy 2017, 168, 26-31. [CrossRef]

6. Breuer, P.; Dai, X.; Jeffrey, M. Leaching of gold and copper minerals in cyanide deficient copper solutions. Hydrometallurgy 2005, 78, 156-165. [CrossRef]

7. Alonso-González, O.; Nava-Alonso, F.; Uribe-Salas, A. Copper removal from cyanide solutions by acidification. Miner. Eng. 2009, 22, 324-329. [CrossRef]

8. Alonso-González, O.; Nava-Alonso, F.; Jimenez-Velasco, C.; Uribe-Salas, A. Copper cyanide removal by precipitation with quaternary ammonium salts. Miner. Eng. 2013, 42, 43-49. [CrossRef]

9. Gonen, N.; Kabasakal, O.; Özdil, G. Recovery of cyanide in gold leach waste solution by volatilization and absorption. J. Hazard. Mater. 2004, 113, 231-236. [CrossRef]

10. Xie, F.; Wang, W. Recovery of copper and cyanide from waste cyanide solutions using emulsion liquid membrane with LIX 7950 as the carrier. Environ. Technol. 2016, 38, 1961-1968. [CrossRef]

11. Watling, H. Chalcopyrite hydrometallurgy at atmospheric pressure: 1 . Review of acidic sulfate, sulfate-chloride and sulfatenitrate process options. Hydrometallurgy 2013, 140, 163-180. [CrossRef]

12. Sitando, O.; Senanayake, G.; Dai, X.; Breuer, P. The adsorption of gold(I) on minerals and activated carbon (preg-robbing) in non-ammoniacal thiosulfate solutions-Effect of calcium thiosulfate, silver(I), copper(I) and polythionate ions. Hydrometallurgy 2019, 184, 206-217. [CrossRef]

13. Sajjad, W.; Zheng, G.; Din, G.; Ma, X.X.; Rafiq, M.; Xu, W. Metals extraction from sulfide ores with microorganisms: The bioleaching technology and recent developments. Trans. Indian Inst. Met. 2019, 72, 559-579. [CrossRef]

14. Altinkaya, P.; Mäkinen, J.; Kinnunen, P.; Kolehmainen, E.; Haapalainen, M.; Lundström, M. Effect of biological pretreatment on metal extraction from flotation tailings for chloride leaching. Miner. Eng. 2018, 129, 47-53. [CrossRef]

15. Muir, D. A review of the selective leaching of gold from oxidised copper-gold ores with ammonia-cyanide and new insights for plant control and operation. Miner. Eng. 2011, 24, 576-582. [CrossRef]

16. Bas, A.D.; Koc, E.; Yazici, E.Y.; Deveci, H. Treatment of copper-rich gold ore by cyanide leaching, ammonia pretreatment and ammoniacal cyanide leaching. Trans. Nonfer. Met. Soc. China 2015, 25, 597-607. [CrossRef]

17. Lodeyshchikov, V.M.; Khmelnitskaya, O.D.; Voyloshnikov, G.I. Ammonical cyanidation copper gold-bearing ores. Nonfer. Met. 2010, 8, 37-41. Available online: https:/ / elibrary.ru/item.asp?id=15184230 (accessed on 12 January 2021). (In Russian).

18. Strizhko, L.S.; Bobozoda, S.; Boboyev, I.R.; Berger, B.R. Extraction of gold from gold-copper raw materials. Nonfer. Met. 2014, 6, 41-43. Available online: https:/ / elibrary.ru/item.asp?id=21772936 (accessed on 12 January 2021). (In Russian).

19. Strizhko, L.S. Metallurgy of Gold and Silver; National University of Science and Technology: Moscow, Russia, 2001; p. 336. (In Russian)

20. Hedjazi, F.; Monhemius, A.J. Industrial application of ammonia-assisted cyanide leaching for copper-gold ores. Miner. Eng. 2018, 126, 123-129. [CrossRef]

21. Porvali, A.; Rintala, L.; Aromaa, J.; Kaartinen, T.; Forsen, O.; Lundstrom, M. Thiosulfate-copper-ammonia leaching of pure gold and pressure oxidized concentrate. Physicochem. Probl. Miner. Process. 2017, 53, 1079-1091. [CrossRef] 
22. Boboyev, I.R.; Bobozoda, S.; Strizhko, L.S. Leaching of refractory oxidized gold ore containing copper. Metallurgist 2015, 10, 78-80. Available online: https:/ / elibrary.ru/item.asp?id=24880672 (accessed on 12 January 2021). (In Russian).

23. Kryukov, V.G.; Lavrik, N.A.; Litvinova, N.M.; Stepanova, V.F. Typomorphic minerals oxidation zone of gold-copper porphyry ore of the Malmyzh deposit (Svoboda). Georesursy 2019, 21, 91-98. [CrossRef]

24. Ahn, J.-H.; Kim, P.D.; Hwang, S.C.; Seo, J.; Lee, S.; Ogawa, Y.; Ida, J.; Sasaki, Y.; Nagai, T.; Otsu, T. Electrolyzed Sulfuric Acid Application in Semiconductor Cleaning Processes: An Advanced Substitution of SPM Cleaning. ECS Trans. 2017, 77, 207-212. [CrossRef]

25. Seo, S.; Choi, W.; Kim, M.; Tran, T. Leaching of a Cu-Co ore from Congo using sulphuric acidhydrogen peroxide leachants. J. Min. Metall. Sect. B Metall. 2013, 49, 1-7. [CrossRef]

26. Ozer, M.J. Cobalt and copper recovery from the ancient flotation tailings by selective sulfation roast-leaching process. J. Min. Metall. Sect. B Metall. 2019, 55, 315-324. [CrossRef]

27. Mourad, K.A.; Hobro, S. Developing chlorine-based antiseptic by electrolysis. Sci. Total. Environ. 2020, 709, 136108. [CrossRef]

28. Sekisov, A.; Rasskazova, A.; Konareva, T.; Rasskazov, M.; Korpi, P. Comparative research of cyanide and sulfate-chloride gold leaching from oxidized gold-copper ore. In Proceedings of the 18th International Multidisciplinary Scientific GeoConference SGEM 2018, Albena, Bulgaria, 2-8 July 2018; SGEM: Sofia, Bulgaria, 2018; pp. 35-42. [CrossRef]

29. Rasskazova, A.V.; Sekisov, A.; Kirilchuk, A.G.; Vasyanovich, Y.A. Stage-activation leaching of oxidized copper-gold ore: Theory and technology. Eurasian Min. 2020, 1, 52-55. [CrossRef]

30. Sekisov, A.G.; Rasskazova, A.V. Method of Leaching Gold from Refractory Ores. RU Patent 2647961. Available online: https: / / elibrary.ru/item.asp?id=37366218 (accessed on 12 January 2021). 